International Journal of Applied Linguistics \& English Literature

ISSN 2200-3592 (Print), ISSN 2200-3452 (Online)

Vol. 1 No. 3; July 2012 [Special Issue on World Literature in English]

\title{
The Tragedy of V.S. Naipaul's Miguel Street
}

\author{
Zanyar Kareem Abdul \\ Universiti Putra Malaysia, Malaysia \\ Rohimmi Noor \\ Universiti Putra Malaysia, Malaysia
}

Received: 10-07- 2012

Accepted: 25-07- 2012

Published: 31-07- 2012

doi:10.7575/ijalel.v.1n.3p.63

URL: http://dx.doi.org/10.7575/ijalel.v.1n.3p.63

\begin{abstract}
Sir Vidiadhar Surajprasad (V.S. Naipaul) was born in Trinidad in 1932. His works have been an enduring focus between rich and poor, colonizer and colonized. In The New York Review of Books, Naipaul has been called "'a master of English prose," which indicates his weight in modern literature, especially in post colonialism. The paper depicts a dark area and tragedy in Miguel Street throughout the characters and their dialogues. Naipaul is famous for his sad-given-tonic moment in his novels. The paper also provides examples and explanations behind the tragedy of the novel and what the characters suffer from: misunderstanding, poverty, or losing humanity that no more communication works out. Miguel Street is a place where all the tragic moments happen in the novel. Each section of the story ends with sadness and disappointment.
\end{abstract}

Keywords: Tragic moment, Tragic novel, Trinidad society

Introduction

Miguel Street (1959) is one of Naipaul's outstanding novels and is a semi-autobiographical novel set in Port of Spain, Trinidad. The locations in the novel are of crucial importance-Trinidad and Tobago. Naipaul deliberately chose these two islands which were under British rule until 1962 when they achieved independence.

The novel consists of seventeen sections, and each deals with a different story, with a new title. The novel focuses on the main characters such as Hat, Popo, and the narrator, and their personal lives on Miguel Street. The story is about diversity of life, death, marriage and work on Miguel Street, and conveys a sense of comic-tragedy to the readers. It is told through the eyes of a young child narrator. Naipaul succinctly creates a realistic picture of these characters in the frame of colonization. Barnouw comments, "Critical readings of Naipaul's work have generally been divided into two groups: a strongly-focused post-colonialist critique of his indebtedness to western cultural values that does not deal with the textual complexity, and literary studies of his fictional and non-fictional texts that do not deal with representational complexity, the text's connectedness to social and political realities" (Mukherjee 212).

Naipaul's writing is characterized by a gloomy tragic and dark weather which makes the readers focus on every single moment in his novels. In this paper, the focus is on the tragedy of the novel that Naipaul has established in his own style. There are a lot of sad and painful scenes that this paper touches on. Hedi observes,

Beating is a recurring item in Naipaul's fiction. Characters either beat or are beaten. What is interesting is that beating as a social phenomenon can tell us much about the society and its habits. Beating becomes a ceremony, a ritual conducted at appropriate moments for appropriate purposes. In this ritual there is an equilibrium between the protagonists. Those who beat do not find any resistance from those who are beaten as they are usually either women or children. (Hedi 53)

Miguel Street is a good novel to be studied for the essay and to analyse characters' reaction towards family, friends and people around them. Naipaul has given a lot of examples that denote the tragic moment for everyone in the novel and the readers as well. 
International Journal of Applied Linguistics \& English Literature

ISSN 2200-3592 (Print), ISSN 2200-3452 (Online)

Vol. 1 No. 3; July 2012 [Special Issue on World Literature in English]

\section{Discussion}

Naipaul writes a novel which is full of tragic moments surrounding the characters. This is told through an eight-year-old boy who is the narrator of the novel. The tragedy lies according to the following functions that Naipaul has used to develop his novel: each story has a sad and disappointing ending which indicates a disastrous moment for each character in Miguel Street. For example The story of George and the Pink House ends with the burial with George and MAN-MAN again a terrible ending which culminates in being arrested by the police. Most importantly, in the last section of the novel, How I left Miguel street, the narrator leaves the street for good, having failed to realize his dreams and develop his life. Each section gives a new and different story which deals with a particular character but the end is disappointing. Each character tries to escape from Miguel Street, hoping to find a bright future-somewhere else. Popo is one of the main characters here and the narrator calls him "a man of philosophy," which is quite ironic because Popo is an idle man and has never made money, something for which he is criticized for by the narrator: "Women and them like work. Man not make for work" (Miguel Street 19). Popo does not have an identity, as a result he feels that something is lacking. Popo always tells the boy (narrator), "Boy, the only thing to make is the thing without a name" in which again trouble appears again and brings Popo to jail. Problems and hopelessness can be detected throughout Naipaul's writing as if escape is impossible.

Hat, another main character, is no different. Even though he is regarded as a philosopher in the novel because he has given words and/or quotes for every occasion, nevertheless he still ends up in jail- which upsets the reader and the narrator, who says, "When Hat went to jail, part of me had died" (214). All in all, there are a lot of tragic stories woven into the novel but they are treated as nothing more than "just another week-end tragedy, one of many" (116), like the drowning of Laura's daughter, Lorna. Hope and vitality are lost in the novel in which all characters try to escape from that bitter reality aiming at finding a new way of life anywhere except Miguel street; for Naipaul it is Trinidad in a sorrowful manner where he has given his own voice in the following:

You see, is just what I does tell you, Trinidad people don't know good thing. They just born stupid. Down at the base it have Americans begging me to sing. They know what is what. The other day, working and singing at the base, the colonel come up and tell me I had a nice voice. He was begging me to go to the States (189)

Bolo, another character in the novel, states that he does not want to stay in Trinidad, so Trinidad becomes a nightmare for the people there. In a way, there are two means of escape. First is death, which happens to most of the characters after being quite depressed on Miguel Street. Second, leaving the city might be another means of escaping which is difficult for all except the narrator who leaves Miguel street for good. After realizing nothing can change the situation there, "Disappointed because although I had been away, destined to be gone for good, everything was going on just as before, with nothing to indicate my absence" (222). So, the narrator takes the option to leave the city as he has always been reminded by his mother, "You getting too wild in this place. I think is high time you leave" (215).

Beating and fighting - violence in general - are other tools with which Naipaul denotes his tragedy in the novel, as Hedi (1992) confirms:

Violence is a thoroughly documented item in V.S. Naipaul's fiction. The politics, social and cultural context his characters evolve in makes for antagonism, in all its forms, an essential characteristic of any relationship. This violence and antagonism stand for a barrier against self-realization. This violence is not exclusively physical, it is also intellectual for we consider the process of acculturation, for instance, as a violent act through which the colonizer violates the integrity of a society and its patrimony. (49)

It starts from Popo and Hat who always beat their wives for no clear reasons; added to this, George is one of the abusive characters who exploits his family, including wife and even daughter by beating them. 


\section{International Journal of Applied Linguistics \& English Literature}

ISSN 2200-3592 (Print), ISSN 2200-3452 (Online)

Vol. 1 No. 3; July 2012 [Special Issue on World Literature in English]

[...] he beat them all. And when the boy Elias grew too big, George beat his daughter and his wife more than ever. The blows didn't appear to do the mother any good. She just grew thinner and thinner; but the daughter, Dolly, thrived on it. She grew fatter and fatter, and giggled more and more every year. (27)

Although the comic tone serves here in this statement, Hedi (1992) explains, it sharpens "the cruelty of the father and reveals the resignation of the violated and their submission to the patriarchal power." The mother and the children are dutifully enduring the situations that are numerous and unjustified. What is quite terrible for the society as such is the lack of any "glimmer of hope and sparkle of optimism" as Naipaul draws them succinctly in the novel. Hedi (1992) further elaborates that the cycle of the beating is as follows: husbands beat wives such as Tony and Mrs Hereira; wives beat husbands for instance, Laura and Nathaniel; a father beats his son in the case of George and Elias; and finally, men beat men as one can see the street fellows reaction against Tony: "Antagonism and violence are overwhelming in Miguel Street. The antagonistic relationship between the inhabitants of the street stripped their lives from its convivial aspect. They are individuals fighting for their recognition of their status in the street." (49). Hedi (1992) strongly believes that a vivid example is the narrator who has antagonists such as George, "he was saying 'Horse-face!' Sometimes he said, 'Like it only have horse-face people living in this place" (28-9). On the running discussion, this sort of antagonism is also reflected in others of Naipaul's masterpieces, specifically in A House for Mr. Biswas (1961), in which antagonism becomes a significant theme in the novel. The characters are divided into two groups: Mr. Biswas, including his family, and the community.

The whole idea of the novel is to show the antagonism between him, Mr. Biswas, and the community which he rejects. Mr. Biswas' seclusion is detected throughout the story and in his wish to be away from the outside world.

[...] he tried to think of landscapes without people: sand and sand and sand, without the 'oses' Lal had spoken about; vast white plateaux with himself safely alone, a speck in the centre. Was he afraid of real people? [...] Now he would never be able to go among people. (267)

Mr. Biswas faces a lot of psychological issues including questioning himself about manhood and his strong rejection of community, which aimed at finding his own private life, far from any people: "Such process is necessarily accompanied by violence, for antagonism feeds on violence. Violence is represented as a basic element that characterizes the cohabitation between different groups in Trinidad. Violence is both physical and verbal," Hedi argues.

Furthermore, beating and bullying are other ways of treating people, especially by the narrator's mother, who loves everyone and seems to be loved in return. The world around him (narrator) is surrounded by a severe treatment, which brings a tragedy for the story till the end; therefore, it is an impulse in obliging the childnarrator - to leave the city for the purpose of finding something that makes a change in his life "[...] she beat me rather badly, and I ran out of the house swearing that I would never come back. I went to B. Wordsworth's house. I was so angry, my nose was bleeding" (59-60). This is a reaction to his mother's harsh and destructive words, which always makes a black mark on the development of the personality of the narrator: "my mother slapped me, saying, 'you know, you too fast for a little boy'” (109).

It is noteworthy that each of the characters finds justification of their own action. Those who beat believe that a good education can be earned from beating and those who are beaten do not have a right to complain as one can find out in Miguel Street, which provides many examples of aggression and beating, either verbal or physical, which make the novel more tragic in the eyes of the reader. Naipaul has presented various social phenomena, and beating is one of the aspects which for Naipaul is to "emphasize the absence of order even in matters of beating" (Hedi, 54). Ironically, this is depicted in the scene when Nathaniel does his best to show how one controls a woman. To prove his ability, he leaves the house and shouting after a fight with Laura: "Just been beating some sense into that woman" and he needs to cover his beaten eye. Day by day, Laura beats him in public and chases him: "Irony is a permanent attitude in Naipaul's writing but, it takes a sad and tragic aspect when it comes to dealing with a society where values are up-side-down and where chaos is the rule" (55). 


\section{International Journal of Applied Linguistics \& English Literature}

ISSN 2200-3592 (Print), ISSN 2200-3452 (Online)

Vol. 1 No. 3; July 2012 [Special Issue on World Literature in English]

The same process and beating happens again in A House for Mr. Biswas, where children suffer a lot from maltreatment and beatings, as Hedi states, "beating seems to be a natural process and a compulsory item for the education of the children" (55).

Naipaul brings up a lot of disappointing terms such as "sad, frightening, dark, mad, death, etc." to disseminate a tragic picture in the whole novel which affects the tone of the story to be told. For instance, in the story of $M A N-M A N$, the narrator tells "everybody in Miguel street that MAN-MAN was mad, and so they left him. But I am not so sure now that he was mad, and I can think of many people much madder than MAN-MAN was ever. He didn't look mad." Furthermore, the aforementioned negative terms are applied to the characters - those people who live on Miguel Street- "but we who lived there saw our street as a world, where everybody was quite different from everybody else. Man-man was mad; George was stupid; Big Food was a bully; Hat was an adventurer; Popo was a philosopher, and Morgan was our comedian" (79).

Naipaul is creative in providing tragic and dark stories, he even brings up another story in the novel which shows a perfect image of sadness such as in Wordswoth's part of the book,

Listen, and I will tell you a story. Once upon a time a boy and a girl met each other and they fell in love. They loved each other so much they got married. They were both poets. He loved words. She loved grass and flowers and trees. They lived happily in a single room, and then one day the girl poet said to the boy poet, "We are going to have another poet in the family." But this poet was never born, because the girl died, and the young poet died with her, inside her. And the girl's husband was very sad, and he said he would never touch a thing in the girl's garden. And so the garden remained, and grew high and wild. (61)

Thus, Shivani (2007) has confirmed, “The words 'Naipaul' and 'darkness' are synonymous." It is, indeed, darkness that covers most of Naipaul's works in terms of action, linguistic terms, gloomy atmosphere and even his description,

We walked a little away in the bright moonlight, left the road and climbed down into the swamp. A tired wind blew from the sea, and the smell of stale sea-water was everywhere. Under the coconut tree it was dark. We walked a bit further on. A cloud covered the moon and the wind fell. (182)

These make other scholars castigate what Naipaul tries to convey, as Huggan and Tiffin (2010) have declared, "Naipaul's work is no haven for the literary nature-lover. His despoiled landscapes tell of centuries of human cruelty, greed and plunder" (112). Perhaps this violence and darkness for Naipaul are the signals of the unprogressive place where hope and aims are banded - a lot of barriers in front of being creative and developing Miguel Street.

\section{Conclusion}

Naipaul has creatively made a tragic novel to show the readers the totally dark atmosphere of Trinidad and its people through his sad stories, tone, terms and aggressive violence among the characters. Miguel Street is the place where hope and optimism are quite lost, which makes all the characters disappointed and leads them to fade away. Hedi (1992) concludes:

Naipaul's final aim is to put emphasis on the awkwardness of his characters leaving them roaming amid the ruins of their inefficient actions. Naipaul sees in this violence an abortive enterprise, a proof of weakness and vulnerability. The various aspects of violence as they are represented in Naipaul's fiction affect man in his own existence, threatening him with extinction. (61)

This is what the boy-narrator-and Mr. Biswas fight for while they are deprived of doing so. They seem to surrender as the troubled water does not lead them anywhere. As Hedi puts it, "This is the end-or the dead-end-Naipaul offers his protagonists" (61). 
International Journal of Applied Linguistics \& English Literature

ISSN 2200-3592 (Print), ISSN 2200-3452 (Online)

Vol. 1 No. 3; July 2012 [Special Issue on World Literature in English]

\section{References}

Hedi, Ben Abbes. A Variation of the Theme of Violence and Antagonism in V. S. Naipaul's fiction . Caribbean Studies: 1992, 49-61

Huggan, Graham, Tiffin, Helen. Postcolonial Ecocriticisim. New York: Routledge, 2010. Print

Mukherjee, Pablo. Doomed to Smallness: Violence, V.S Naipaul, and The Global South. 2007, 209-226

Naipaul, V.S. A House for Mr. Biswas. USA: Harmondsworth, 1985. Print

Naipaul, V.S. Miguel Street. New York: Vintage, 1987. Print

Ormerod, David. Theme and Image in V. S. Naipaul's A house for Mr. Biswas. University of Texas, 1967, $589-602$

Sivagurunathan, Shivani. An Area of Darkness?: A Journey through V.S. Naipaul's Miguel Street and Raymond Ramcharitar's The Island Quintet. 2007 http://www.bookrags.com/biography/v-s-naipaul/

\section{Zanyar Kareem Abdul}

Zanyar is currently pursuing her postgraduate studies in English Literature at the Faculty of Modern Languages and Communication, Universiti Putra Malaysia.

\section{Rohimmi Noor}

Rohimmi is a lecturer at the Faculty of Modern Languages and Communication, Universiti Putra Malaysia. His research interest includes postcolonial literature, modernist writers, and literary criticism. 